\title{
OCCURRENCE OF BASKING SHARK, CETORHINUS MAXIMUS (ELASMOBRANCHII: LAMNIFORMES: CETORHINIDAE), OFF THE SYRIAN COAST (EASTERN MEDITERRANEAN) WITH FIRST DESCRIPTION OF EGG CASE
}

\author{
Malek ALI ${ }^{1}$, Adib SAAD ${ }^{1}$, Christian REYNAUD ${ }^{2}$, and Christian CAPAPÉ ${ }^{3 *}$ \\ ${ }^{1}$ Marine Sciences Laboratory, Faculty of Agriculture, Tishreen university, Lattakia, Syria \\ ${ }^{2}$ Laboratoire interdisciplinaire de Recherche en Didactique, Éducation et Formation, E.A. 3749, case 77, \\ Université Montpellier II, Sciences et Techniques du Languedoc, 34095 Montpellier cedex 5, France \\ ${ }^{3}$ Laboratoire d'Ichtyologie, Université Montpellier II, Sciences et Techniques du Languedoc, \\ 34095 Montpellier cedex 5, France
}

Ali M., Saad A., Reynaud C., Capapé C. 2012. Occurrence of basking shark, Cetorhinus maximus (Elasmobranchii: Lamniformes: Cetorhinidae), off the Syrian coast (eastern Mediterranean) with first description of egg case. Acta Ichthyol. Piscat. 42 (4): 335-339.

\begin{abstract}
The authors report in this paper the first record of basking shark, Cetorhinus maximus (Gunnerus, 1765), off the coast of Syria (eastern Mediterranean). The specimen was an adult female, $690 \mathrm{~cm}$ total length and weighing approximately $2.5 \mathrm{t}$. It was a pregnant female at the beginning of gestation and contained 34 egg cases. The first description of C. maximus egg case is provided with short comments on the reproductive biology of the species.
\end{abstract}

Keywords: Chondrichthyes, Cetorhinidae, Cetorhinus maximus, first record, egg case, Syrian coast, Mediterranean

Basking shark, Cetorhinus maximus (Gunnerus, 1765), is a large shark, distributed worldwide, generally found in boreal to warm temperate waters, frequently sighted in open seas, and which often enters into enclosed bays where it is usually captured; additionally, some dead specimens are found stranded on the beach (Compagno 1984). The presence of basking shark is known in the Mediterranean, but most of the reported captures were from western and central areas (Mancusi et al. 2005), especially off the Maghreb coast (Capapé et al. 2005) and the Adriatic Sea (Lipej et al. 2000, Soldo et al. 2008).

Conversely, C. maximus appears to be less frequently captured in the eastern Mediterranean basin, from the Turkish coast (Kabasakal 2002, Kabasakal and Kabasakal 2004, Golani et al. 2006) to Levant Basin (Golani 2005). It has hitherto not been reported off Lebanon (Mouneimne 1977, 1979) and Syria, where through surveys conducted from January 2000 to date, 42 elasmobranch species have already been identified (Saad et al. 2004, Ali et al. 2010).

During these surveys, a female C. maximus was captured on 20-21 April 2012 by gill-net, spread from the beach to $150 \mathrm{~m}$ in the sea, at a depth of approximately 10 metres, off Raas Albassit, city located in northern Syria $\left(35^{\circ} 50^{\prime} 50^{\prime \prime} \mathrm{N}\right.$, $35^{\circ} 48^{\prime} 16^{\prime \prime} \mathrm{E}$; Fig. 1). The specimen was a female measuring $6.90 \mathrm{~m}$ in total length and weighing $2.5 \mathrm{t}$ (Fig. 2). Its identification was aided by Bigelow and Schroeder (1948),

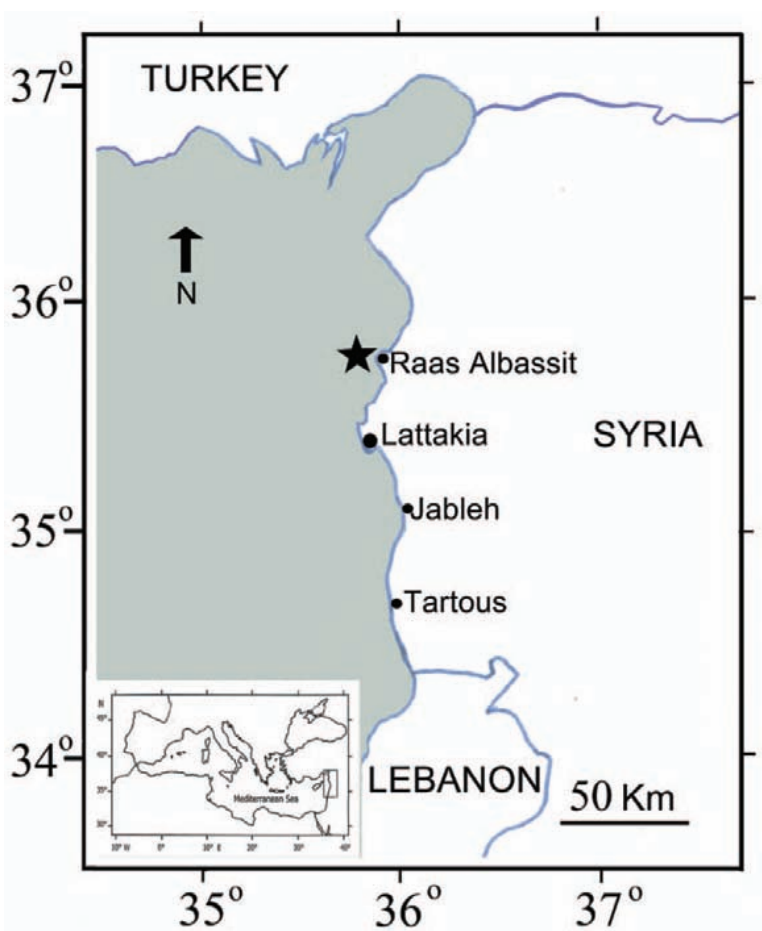

Fig. 1. Map of the Mediterranean showing Syria and map of the coast of Syria pointing out the capture site of the pregnant female Cetorhinus maximus (black star)

\footnotetext{
${ }^{*}$ Correspondence: Dr Christian Capapé, Laboratoire d'Ichtyologie, case 104, Université Montpellier II, Sciences et Techniques du Languedoc, 34095 Montpellier cedex 5 , France, phone: +33467544162, e-mail: capape@univ-montp2.fr.
} 
Compagno (1984), and Quéro (1984), based on: 5 extremely huge gill-slits virtually encircling the head, gill arches with bristle-like rakers, pointed snout, large sub-terminal mouth with numerous minute hooked teeth, caudal peduncle with strong lateral keels, lunate caudal fin nearly asymmetrical. Measurements were carried out directly at Lattakia fish market, following methodology of Compagno (1984) for sharks, and recorded to the nearest $\mathrm{cm}$. The absolute values were also related to the percentage of total length (Table 1).

The female was cut up in a hurry by fishermen and rapidly sold, the abdominal cavity was opened and 34 egg cases were found in the body liquids (Fig. 3). Unfortunately, a single egg case could be collected; it was deposited in the Ichthyological Collection of the Marine Sciences Laboratory, Agriculture Faculty, Tishreen University of Syria, under the catalogue number 251 M.S.L. (Fig. 4).

The egg case was studied and presented herein, following the methodology proposed by Oddone et al.
(2006) and Oddone and Vooren (2008) for skate species. The egg case, $96 \mathrm{~mm}$ length and $46 \mathrm{~mm}$ width, was globally ovoid, symmetrically convex with a highest point centrally located; it was keeled longitudinally, and its anterior margin was curved, with on each corner a hornlike short projection, followed by anterior tendril of $87 \mathrm{~mm}$ length, rounded in cross section of $3 \mathrm{~mm}$ diameter, exhibiting two short curved expansions. The case corpus was followed by a posterior horn, sharp and triangular, measuring $68 \mathrm{~mm}$ in length, $26 \mathrm{~mm}$ in maximum width, and $12 \mathrm{~mm}$ in minimum width, ended by a filament measuring $90 \mathrm{~mm}$ in length, $8 \mathrm{~mm}$ in maximum width and $4 \mathrm{~mm}$ in minimum width. The complete egg case weighed 40.39 g. Two empty cases weighed 9.49 and $9.37 \mathrm{~g}$, respectively with an average of $9.43 \pm 0.08 \mathrm{~g}$, so the egg weighed $30.96 \mathrm{~g}$ approximately.

This large female $C$. maximus contained egg cases in the uterus, was at the beginning of the gestation, and it could be
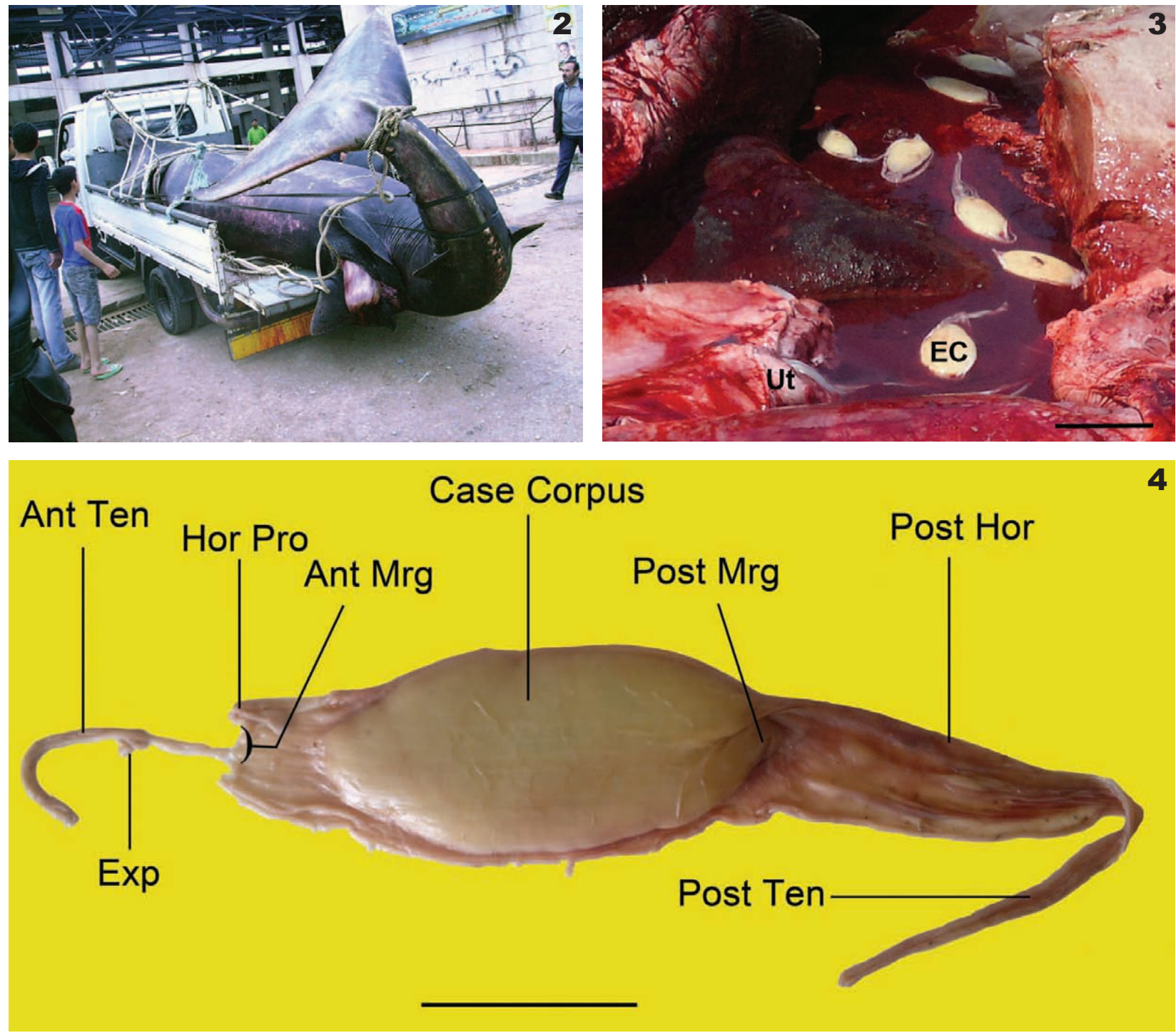

Figs. 2-4. Pregnant female of Cetorhinus maximus captured off the coast of Syria; Fig. 2. Entire specimen loaded on a truck; Fig. 3. Egg cases (EC) outside the uterus (Ut); Scale bar = 100 mm; Fig. 4. Single egg case; Ant Ten = anterior filament; Ant Mrg = anterior margin; Exp = expansions; Hor Pro = horny process; Post Ten = posterior filament; Post Hor = posterior horn; Post Mrg = posterior margin; Scale bar $=50 \mathrm{~mm}$ 
Table 1

Morphometric measurements (absolute and relative values) recorded in the pregnant female of Cetorhinus maximus captured off the coast of Syria

\begin{tabular}{|c|c|c|}
\hline \multirow{2}{*}{ Morphometric character } & \multicolumn{2}{|c|}{ Value } \\
\hline & Absolute $[\mathrm{cm}]$ & Relative [\% TL] \\
\hline Total length & 690 & 100.0 \\
\hline Pre-second dorsal fin length & 475 & 68.8 \\
\hline Pre-first dorsal-fin length & 244 & 35.4 \\
\hline Head length & 128 & 18.6 \\
\hline Pre-branchial length & 90 & 13.0 \\
\hline Pre-spiracular length & 62 & 9.0 \\
\hline Pre-orbital length & 32 & 4.6 \\
\hline Pre-pelvic-fin length & 375 & 54.3 \\
\hline Pre-anal-fin length & 485 & 70.3 \\
\hline Pelvic-fin anal-fin space & 74 & 10.7 \\
\hline Pre-narial length & 18 & 2.6 \\
\hline Pre-oral length & 27 & 3.9 \\
\hline Eye length & 7 & 0.9 \\
\hline Eye ball length & 5 & 0.7 \\
\hline Cornea & 2 & 0.2 \\
\hline Pectoral fin anterior margin & 120 & 17.4 \\
\hline Pectoral-fin base & 40 & 5.8 \\
\hline Pectoral-fin inner margin & 24 & 3.5 \\
\hline Pectoral-fin posterior margin & 105 & 15.2 \\
\hline Dorsal caudal-fin margin & 143 & 20.7 \\
\hline Preventral caudal-fin margin & 95 & 13.8 \\
\hline Upper postventral caudal-fin margin & 90 & 13.0 \\
\hline Lower postventral caudal-fin margin & 68 & 9.9 \\
\hline Caudal-fin fork width & 52 & 7.5 \\
\hline Terminal caudal-fin margin & 21 & 3.0 \\
\hline Terminal caudal-fin lobe & 25 & 3.6 \\
\hline First dorsal-fin anterior margin & 52 & 7.5 \\
\hline First dorsal-fin base & 55 & 8.0 \\
\hline First dorsal-fin height & 44 & 6.4 \\
\hline First dorsal-fin inner margin & 15 & 2.2 \\
\hline First dorsal-fin posterior margin & 58 & 8.4 \\
\hline Second dorsal-fin anterior margin & 25 & 3.6 \\
\hline Second dorsal-fin base & 18 & 2.6 \\
\hline Second dorsal-fin inner margin & 27 & 3.9 \\
\hline Second dorsal-fin posterior margin & 22 & 3.2 \\
\hline Pelvic-fin anterior margin & 50 & 7.2 \\
\hline Pelvic-fin base & 58 & 8.4 \\
\hline Pelvic-fin height & 28 & 4.1 \\
\hline Pelvic-fin inner margin [length] & 15 & 2.2 \\
\hline Pelvic-fin posterior margin [length] & 58 & 8.4 \\
\hline Anal-fin length & 23 & 3.3 \\
\hline Anal-fin anterior margin & 24 & 3.5 \\
\hline Anal-fin base & 28 & 4.1 \\
\hline Anal-fin inner margin & 16 & 2.3 \\
\hline
\end{tabular}


cont. Table 1

\begin{tabular}{lrr}
\hline \multirow{2}{*}{ Morphometric character } & \multicolumn{2}{c}{ Value } \\
\cline { 2 - 3 } Anal-fin posterior margin & Absolute [cm] & Relative [\% TL] \\
Abdomen height & 21 & 3.0 \\
Second dorsal-fin insertion anal-fin insertion & 110 & 15.9 \\
Mouth length & 7 & 1.0 \\
Mouth width & 42 & 6.1 \\
Nostril width & 94 & 13.6 \\
Internarial space & 13 & 0.9 \\
Tail width & 65 & 1.9 \\
Caudal-fin peduncle width & 29 & 9.4 \\
\hline
\end{tabular}

$\% \mathrm{TL}=$ percentage of total length.

considered as a pregnant specimen, the second recorded to date. The first record was made by a Norwegian fisherman who caught a female ready to give birth to large near-term embryos (Sund 1943). Catches of basking sharks exclusively concern non-pregnant females (Watkins 1958, Mancusi et al. 2005). Matthews (1950) recorded a nonpregnant female $C$. maximus having large number of small eggs in their ovaries. Compagno (1984) and Kunzlik (1988) suggest that the species is ovoviviparous and has uterine cannibalism like other lamnoids, with embryos feeding on the small eggs. Such hypothesis is not suitable due to the fact that the species exhibits minute teeth and is planktonophagous. Additionally, the eggs found in this female-rather large and heavy-showed that $C$. maximus is unable to assume this reproductive strategy. On the other hand, C. maximus is not a true ovoviviparous elasmobranch species such as whale shark, Rhincodon typus Smith, 1828, in which embryo development is protected by a rigid capsule in female uterus (Joung et al. 1996).

At maturity, female basking sharks reach the size of 8.1-9.8 $\mathrm{m}$ (Compagno 1984). The specimen described in the present paper showed that females could mature at smaller-size, which would be consistent with Bigelow and Schroeder (1948) who noted that they matured between the length of 457 and $610 \mathrm{~cm}$. Gilmore (1993) noted that parturition size occurred when the embryos reached $150 \mathrm{~cm}$ total length and the smallest free-swimming specimen was $165 \mathrm{~cm}$ total length. Compagno (1984) noted that gestation period of basking shark lasted between 12 and 36 months. The small size and low weight of eggs collected and-on the contrary - the large size of neonates (observed elsewhere) suggest a substantial transfer of nutrients from the mother to the embryos. Such transfers probably require a long period of time. The length of this period, however, still remains obscure and requires further records to be clearly assessed. The presently reported fecundity per litter (34 eggs) does not appear very low for an elasmobranch species, for instance, Capapé (1985) recorded a minimum fecundity of one specimen per litter in gulper shark, Centrophorus granulosus (Bloch and
Schneider 1801). This first record of C. maximus off the Syrian coast confirms the rarity of the species throughout the Mediterranean Sea. The capture of a pregnant female in shallow coastal waters is probably occasional, but remains also questionable with special regard to an isolate and declining population still existing in the region.

\section{REFERENCES}

Ali M., Saad A., Ben Amor M.M., Capapé C. 2010. First records of the Honeycomb Stingray, Himantura uarnak (Forskål, 1775), off the Syrian coast (eastern Mediterranean) (Chondrichthyes: Dasyatidae) Zoology in the Middle East 49: 104-106.

Bigelow H.B., Schroeder W.C. 1948. Sharks. Pp. 59-546. In: Tee-Van J., Breder C.M., Hildebrand S.F., Parr A.E., Schroeder W.C. (eds.) Fishes of the western North Atlantic. Memoirs of the Sears Foundation for Marine Research No. 1. Part 1. Yale University, New Haven, CT, USA.

Capapé C. 1985. Propos sur la fécondité des poissons sélaciens. Archives de l'Institut Pasteur de Tunis 62 (3): 305-328.

Capapé C., Hemida F., Bensaci J., Saïdi B., Bradaï M.N. 2005. Records of basking sharks, Cetorhinus maximus (Gunnerus, 1765) (Chondrichthyes: Cetorhinidae) off the Maghrebin shore (southern Mediterranean): a survey. Annales, series Historia Naturalis 13 (1): 13-18.

Compagno L.V.J. 1984. FAO species catalogue. Vol. 4. Sharks of the world. An annotated and illustrated catalogue of sharks species known to date. Part 2. Carcharhiniformes. FAO Fisheries Synopsis No. 125, Volume 4, Part 1. FAO, Rome, Italy.

Gilmore R.G. 1993. Reproductive biology of lamnoid sharks. Environmental Biology of Fishes 38 (1-3): 95-114. DOI: $10.1007 /$ BF00842907

Golani D. 2005. Check-list of the Mediterranean fishes of Israel. Zootaxa 2005 (947): 1-90.

Golani D., Oztürk B., Basusta N. 2006. Fishes of the eastern Mediterranean. Turkish Marine Research Foundation, Istanbul, Turkey.

Joung S.-J., Chen C.-T., Clark E., Uchida S., Huang W.Y.P. 1996. The whale shark, Rhincodon typus, is a livebearer: 300 embryos found in one 'magamamma' supreme. 
Environmental Biology of Fishes 46 (3): 219-233. DOI: 10.1007/BF00004997

Kabasakal H. 2002. Capture of a female basking shark, Cetorhinus maximus (Gunnerus, 1765), from southern Turkey. Annales, series Historia Naturalis 12 (1): 31-34.

Kabasakal H., Kabasakal E. 2004. Sharks captured by commercial fishing vessels off the coast of Turkey in the northern Aegean Sea. Annales, series Historia Naturalis 14 (2): 171-180.

Kunzlik P.A. 1988. The basking shark. Scottish Fisheries Information. Pamphlet No. 14. Department of Agriculture and Fisheries for Scotland, Aberdeen.

Lipej L., Makovec T., Orlando M., Ziza V.. 2000. Occurrence of the basking shark, Cetorhinus maximus (Gunnerus, 1765), in the waters off Piran (Gulf of Trieste, Northern Adriatic). Annales, series Historia Naturalis 10 (2): 211-216.

Oddone M.C., Mesa A., De Amorim A.F. 2006. The egg capsule of Rioraja agassizi (Müller \& Henle) (Elasmobranchii, Rajidae), endemic to the SW Atlantic. Pan-American Journal of Aquatic Sciences 1 (2): 41-43.

Oddone M.C., Vooren C.M. 2008. Comparative morphology and identification of egg capsules of skate species of the genera Atlantoraja Menni, 1972, Rioraja Whitley, 1939 and Sympterygia Müller \& Henle, 1837. Arquivos de Ciências do Mar 41 (2): 5-13.

Mancusi C., Clò S., Affronte M., Bradaï M.M., Hemida F., Serena F., Soldo A., Vacchi M. 2005. On the presence of basking shark (Cetorhinus maximus) in the Mediterranean Sea. Cybium 29 (4): 399-405.
Matthews L.H. 1950. Reproduction in the basking shark, Cetorhinus maximus (Gunner). Philosophical Transactions of the Royal Society of London: B Biological Sciences $\mathbf{2 4 3}$ (612): 247-316.

DOI: $10.1098 /$ rstb. 1950.0003

Mouneimne N. 1977. Liste des poissons de la côte du Liban (Méditerranée orientale). Cybiu 3 ème série 1: 37-66.

Mouneimne N. 1979. Poissons nouveaux pour les côtes libanaises (Méditerranée orientale). Cybium 3 ème série, 6 : 105-110.

Quéro J.C. 1984. Cetorhinidae. Pp. 87-88. In: Whitehead P.J.P., Bauchot, M.L., Hureau J.C., Nielsen J., Tortonese. E. (eds.) Fishes of the north-western Atlantic and the Mediterranean. Vol. I. UNESCO, Paris, France.

Saad A., Séret B., Ali M. 2004. Liste commentée des Chondrichthyens de Syrie. Rapport de la Commission internationale pour l'exploration scientifique de la mer Méditerranée 37: 430.

Soldo A., Lucic D., Jardas I. 2008. Basking shark (Cetorhinus maximus) occurrence in relation to zooplankton abundance in the eastern Adriatic Sea. Cybium 32 (2): 103-109.

Sund O. 1943. Et Brugdebrasel. Naturen 67: 285-286.

Watkins A. 1958. The sea my hunting ground. Heinemann, London, UK.

Received: 17 May 2012

Accepted: 15 November 2012

Published electronically: 31 December 2012 